\title{
Comprehensiveness in the perspective of public health: pathways for the training of the nurse
}

\author{
Integralidade na perspectiva da saúde coletiva: caminhos para a formação do enfermeiro \\ Integralidad bajo la perspectiva de la salud colectiva: caminos para la formación del enfermero
}

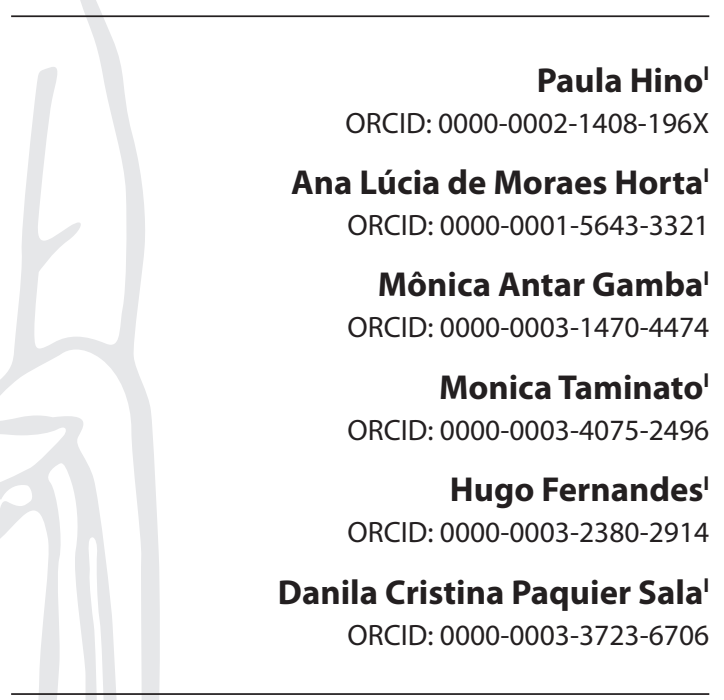

'Universidade Federal de São Paulo. São Paulo, São Paulo, Brazil.

How to cite this article: Hino P, Horta ALM, Gamba MA, Taminato M, Fernandes H, Sala DCP. Integrality in the perspective of collective health: pathways for the formation of the nurse.

Rev Bras Enferm. 2019;72(4):1119-23. doi: http://dx.doi.org/10.1590/0034-7167-2018-0443

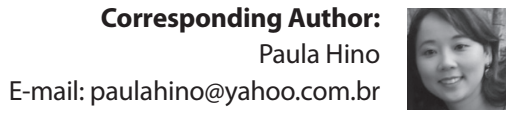

Submission: 09-06-2018 Approval: 09-29-2018

\section{ABSTRACT}

Objective: to present an academic practice experienced by professors in a curricular unit of the public health field entitled "Comprehensive health care", offered in the undergraduate nursing course of a public university. Methods: experience report of dialogic activities between professors and undergraduates. Results: it was possible to discuss nursing care from the perspective of comprehensiveness, which allowed the understanding of the need to broaden the scope regarding the practices conducted in primary care and enabled the attribution of new meanings to the actions experienced by undergraduate students in their curricular internships; thus, contributing to the training of a professional with critical and creative capacity. Final Considerations: the students were able to understand that quality care should go beyond complaintbehavior, providing care based on a networked health service structure aligned with SUS policies and programs.

Descriptors: Comprehensive Care; Community Health Nursing; Public Health; Nursing Education; Primary Health Care.

\section{RESUMO}

Objetivo: apresentar uma prática acadêmica vivenciada por docentes em uma unidade curricular do campo da saúde coletiva intitulada "Integralidade à atenção à saúde", oferecida na graduação em enfermagem de uma universidade pública. Método: relato de experiência de atividades dialógicas entre docentes e graduandos. Resultados: foi possível discutir o cuidado de enfermagem sob a perspectiva da integralidade, o que permitiu compreender a necessidade de ampliar o olhar em relação às práticas realizadas na atenção básica, ressignificar as ações vivenciadas pelos graduandos nos diversos cenários de estágio percorridos e, desta forma, contribuir para formar profissionais com capacidade crítica e criativa. Considerações finais: os graduandos foram capazes de compreender que um atendimento com qualidade deve ir além da queixa-conduta, proporcionando um cuidado apoiado em uma estrutura de serviço de saúde em rede, alinhado às políticas e aos programas do Sistema Único de Saúde. Descritores: Integralidade em Saúde; Enfermagem em Saúde Comunitária; Saúde Pública; Educação em Enfermagem; Atenção Primária à Saúde.

\section{RESUMEN}

Objetivo: presentar una práctica académica vivenciada por docentes en una unidad curricular del campo de la salud colectiva titulada "Integralidad a la atención a la salud", ofertada en el grado en Enfermería de una universidad pública. Métodos: relato de experiencia de actividades dialógicas entre docentes y graduandos. Resultados: fue posible discutir el cuidado de enfermería bajo la perspectiva de la integralidad, lo que permitió comprender la necesidad de ampliar la mirada en relación con las prácticas realizadas en la Atención Básica, así como posibilitó resignificar las acciones vivenciadas por los graduandos en las diversas etapas recorridas y, de esta forma, contribuir a formar un profesional con capacidad crítica y creativa. Consideraciones finales: los graduandos fueron capaces de comprender que una atención con calidad debe ir más allá de la queja-conducta, proporcionando un cuidado apoyado en una estructura de servicio de salud en red, alineado a las políticas del SUS y sus programas.

Descriptores: Integralidad en Salud; Enfermería en Salud Comunitaria; Salud Pública; Educación en Enfermería; Atención Primaria de Salud. 


\section{INTRODUCTION}

To understand patients from the perspective of comprehensive care, considering their particularities, needs and problems, is a challenge for health care. Although the origin of the concept of completeness dates back to the Brazilian Health Reform in the 1970s, it was from the promulgation of the 1988 Federal Constitution and then, from the establishment of Law 8.080/90, that health actions and services in Brazil began to be planned in a comprehensive way. Since then, many efforts have been made to create regulatory and constitutive policies that act as imageobjective, constituting values that converge to achieve fair and supportive health practices ${ }^{(1)}$.

However, a historical and context-based analysis on the contributions of this principle for the application of health technologies in the micropolitical level shows that the transformation of the professional care dimension has not followed the evolution of governmental policies and programs. At the macropolitical level, collective bodies responsible for the administration of health also take asymmetric decisions, influenced by power relations between the three government spheres, leading to fragmented care and obstacles in the administration and regionalization of health care ${ }^{(1)}$.

Comprehensive care is a polysemic concept that was initially attributed as one of the principles of the Brazilian Unified Health System (SUS), which refers to a care that integrates and prioritizes preventive activities, without disregarding care activities. This article adopted the framework proposed by Rubem Mattos - which is based on three dimensions of comprehensive care - and used it as an invitation to reflect on the process of collective construction of the limits and potentialities of comprehensive care in the political context, systems and health practices ${ }^{(2)}$.

The first dimension of comprehensive care highlights the trait of good medicine, which is a critique of the hegemonic practice that privileges the biological dimension through medical specialties and disregards social and psychological aspects. Therefore, this sense of comprehensive care focuses on the practices of health professionals, since the encounter between the professional and the patient allows the recognition of needs that are often not verbalized and that are not directly related to the disease, such as situations of vulnerability, suffering and even the need of hospitalization. The second dimension refers to comprehensive care as a way of organizing health services and practices, contrary to the separation between health care and public health practices. This dimension thus highlights the need to overcome care organized through vertical programs, towards a care that not only meets the programmed needs, but also values the provision of health services horizontally, with the capacity to articulate both programmed and spontaneous demands to respond more adequately to the patient's needs. Finally, the third dimension of comprehensive care assigns the government with the responsibility to administrate with certain public health problems and considers the so-called special policies, which are governmental responses to certain health problems or needs, whose proposal must encompass the possibilities of care and of prevention ${ }^{(2)}$.

Therefore, from the perspective of comprehensive care, patients cannot be reduced to the disease that causes them to suffer. Broadening the notion of health care is necessary, considering the needs and adequacy of the offer of health actions according to the contexts in which the subject meets the health team ${ }^{(2)}$.

\section{OBJECTIVE}

To report the experience of professors in the health area of a public university in São Paulo, Brazil, in the construction of knowledge from the perspective of comprehensive care.

\section{METHODS}

This is a descriptive study of experience report type, prepared as the product of activities developed in 2017 in the course entitled "Comprehensive health care", offered by professors of the Department of Public Health for undergraduates enrolled in the third year of the nursing course of a public university in the city of São Paulo, Brazil.

Experience report is defined as a methodology of observation of reality, which describes a practice or experience that must be related to the relevant theoretical bases. Moreover, this methodology registers the set of situations of practice in a given period of time, preferably recent, since such situations would disappear if they were not documented ${ }^{(3)}$.

This course aims to promote reflection and discussion of the different dimensions of comprehensive care in health care, as well as to develop skills in the care for individuals, families and the community, in a comprehensive manner in the different points of the health care network. The course thus sought to foster the critical reflection of students by articulating the theoretical content with the situations experienced in curricular internships, using active methodologies that favor the teaching-learning process. The development of the curricular unit was based on the precepts of Paulo Freire's pedagogy, who presents a critique of banking education and defends a critical and reflexive view as a transforming and critical action on reality, centered on the search for autonomy, where professors and students are protagonists in the learning process ${ }^{(4)}$.

\section{Description of the experience}

The first meeting was based on presenting and discussing the concept of comprehensive care from a referential used in the field of public health ${ }^{(2)}$. Following, an activity was proposed to the students so, in pairs, they could make a detailed report of a case of care experienced in their internships, and then discuss this case considering the comprehensiveness of care proposed by the authors used. To reflect on the students' perceptions about the health system, as patients or future professionals, and what they believed would be an ideal health system, the third meeting comprised a round-table discussion based on the reflection:"The health care we have and the health care we want".

The next activity used the teaching of a complex case as the strategy, from which the students analyzed the determinants of the life and work context that possibly caused the member of a family to grow sick, the therapeutic pathway, the establishment of the diagnosis and the onset of treatment. The discussions based on this single case enabled several questions to be raised, such 
as reflection on the health perception of patients and health professionals, debates about situations of vulnerability of the territory, how the absence of the State in the neighborhood is reflected on the population's health conditions, the understanding of the organization and structure of the public health system, the importance of public policies and intersectoriality, the dynamics of the work process in the production of primary health and ways of coping with the needs and worsening of health conditions.

A comprehensive panel was created to favor group work, experience exchanges, the integration and incorporation of concepts, ideas and values, as well as the deepening of knowledge on the theme. The groups discussed the following questions: what personal characteristics does the patient present due to being hypertensive? What characteristics related to living and working conditions have influenced the patient's ill-

ness? What does the health service offer to the patient and his family for the care of chronic conditions? What does primary care offer as possibilities for comprehensive care? How can primary, specialized and hospital care be organized to offer comprehensive care? Which and how do public policies support these practices?

The results of the questions were used to develop a therapeutic project based on the health needs, articulating the multiprofessional team in the various spots of care and using the care line, a micromanagement instrument used to compose the thematic networks of health care. The professors verified that undergraduates recognized that identifying health needs from biological, psychological and social points of view is fundamental for ensuring comprehensive care, as well as proposing care interventions for individuals and their families via care strategies based on expanded general practice to strengthen the bond and the dialogue, valuing the work of the multiprofessional and interdisciplinary teams based on health care networks and public policies.

The results of the integrated panel were condensed to be used as the evaluation instrument of the curricular unit, being analyzed considering the three dimensions of comprehensive care $^{(2)}$ (Figure 1).
Aiming to deepen the development of the therapeutic project in complex scenarios, the production of seminars was suggested. The themes were listed by undergraduates from their experiences in internships, namely: vulnerable older adults, women's health in the prison system, violence against children, mourning in the family, childhood accidents, alcohol and drug abuse, moral harassment, among others. Some guidelines were presented for the development of the seminars, which should include the presentation of the case/ situation, the contextualization of the theme, the presentation of the care plan (problems, nursing diagnoses, interventions and expected results), the production of the patient's care pathway over the different care levels, and the use of the dimensions of comprehensive care.

\section{DISCUSSION}

All activities developed in the course "Comprehensive health care" allowed undergraduate students to be the protagonists of the knowledge construction process through case studies, experiences or themes present in the landscape of health in Brazil. To feel as a character in the discussed situation enabled the reflection and decision-making of the students, as well as the 
greater autonomy and understanding of the nurses' performance in public health.

The teaching-learning process adopted in this curricular unit allowed the understanding of a practice that must be offered in a more comprehensive way, seeking to improve the care provided according to the population's health needs. This experience report is thus in line with the objective proposed in the university's political and pedagogical project, which aims to train nurses capable of analyzing and acting critically, with competence in the different contexts of the health-disease-care process, and being based on the humanitarian, ethical and scientific principles that guide the principles of SUS.

The valuation of the students' prior experiences and knowledge, added to the concept of comprehensive care, enabled the enrichment of the perception of complex situations experienced in the health services and by the health professional, as well as a reflection on possible interventions to face different realities. The approach of the themes and the understanding of the phenomena were conducted based on the social determination of the health-disease process, given the relation between the ways of living, of falling ill and of dying, the individual's position in society, and how society is structured ${ }^{(5)}$. The discussion of the themes thus considered the living and working conditions, family and support relationships, the meaning of growing ill, among others.

Comprehensive care represents a fundamental role as a political axis of care and object of reflection, and must permeate the training process of nurses since the understanding of the concept reflects the subjectivity of individuals, their personal, philosophical and experimental experiences. Therefore, the potential of this concept and how it is used requires breaking away from vertical actions and the traditional method of teaching, as well as considering on the students' experiences, valuing them to make them protagonists of the changes. These students must understand how to use this concept through integrative and participative methodologies that incorporate other fields of knowledge, such as the humanities and social sciences ${ }^{(6)}$.

A study that sought to understand how comprehensive care was performed in a basic health unit of the city of São Paulo showed that there are still many challenges to be overcome to guarantee a welcoming environment, based on the practice of comprehensive care that meets the population's health needs. For such, some fundamental conditions can be highlighted such as changes in the daily activities of the service, team co-responsibility, multiprofessional work and discussions that seek quality of the care offered ${ }^{(7)}$.

Several studies have addressed comprehensive care in the context of nursing ${ }^{(6,8-9)}$, reinforcing the importance and value of this concept for an area that is specialized knowledge in care and in people. A study with nurses working in the Brazilian Family Health Strategy, whose objective was to know their perceptions about the completeness of the human being in the practice of care, showed that the participants conceived the same meanings of comprehensive care as the ones adopted in this article since they recognized that the patient must to be cared for as a whole - i.e., in all his/her particularities -, that the work must be multiprofessional and humanized, and that the work process must go beyond institutional protocols so the care practice considers the care networks ${ }^{(8)}$.

Another study also reinforced the importance of comprehensive care in the training of nurses when considering the importance of creating situations that stimulate reflection through real and concrete situations experienced in health services. From the elaboration of care strategies that seek to meet the needs of people from different contexts of life and work, practical-reflexive teaching is believed to allow undergraduate students to develop - through critical thinking and decision-making -, a reflexive practice based on comprehensive care precepts. For such, the need for a collective construction is highlighted since the demands of the teachinglearning process emerge from the experiences of the students, and from the capacity to elicit the discussions from these experiences ${ }^{(9)}$.

Regarding the current educational scenario, it is known that the traditional form of teaching, which considers the teacher as the holder of knowledge and the student as a mere spectator, is not sufficient to ensure learning. The planning of this curricular unit was thus based on the belief of the importance of the active role of undergraduate students in their learning process, valuing the critical thinking and problem-solving capacity in the perspective of comprehensive care.

Through dynamic classes and the incentive to collective participation according to the experiences acquired during curricular internships or extension projects, the comprehensive care approach allowed the exchange of knowledge and the collective construction of coping strategies to each situation from the understanding of interdisciplinary teamwork that is interconnected to the different levels of the health care network, factors necessary to achieve comprehensive care.

Reflecting on previously selected cases to be analyzed in the meetings allowed the students to reflect on the strategies and methods to articulate actions, knowledge, practices and subjects, seeking to enhance some fundamental elements for quality care in accordance with the real health needs of individuals and their families, and that these needs encompass the guarantee of comprehensive, resolvent and humane care, according to the singularity of each patient.

It was possible to observe the students' commitment to the proposed activities that required active participation, both in the reading or reflection phase of a given care service and in the construction of the seminars and exposition of the content discussed as a group. The professors acted as mediators of the work, debating the points raised on a certain subject.

The use of active methodologies, such as case simulation, is important from the pedagogical point of view since it favors the teaching-learning process by enabling students to experience a situation, and, from their theoretical knowledge, actively and responsibly participate in the elaboration of a care plan that addresses the biological, psychological and social needs of patients in a comprehensive way ${ }^{(10)}$.

\section{Study limitations}

When the curricular unit had ended, there was a moment for discussion with the undergraduates about the way the content was presented, the topics that were addressed and the suggestions for its improvement, seeking to construct practices based on the dimensions of comprehensive care. However, to evaluate a pedagogical strategy was not a desire initially, reason why a project was not submitted for ethical appreciation. As a limitation of this study, the authors acknowledge that the incorporation of the results from the evaluation of the students would be pertinent 
to show their perceptions. However, since this is an experience report, it is believed that the proposed objective was not harmed.

\section{Contributions to the field of nursing, health or public policy}

This study found that the experience of the curricular unit based on comprehensive health care allowed a favorable learning environment for the creation of spaces for discussion on how to use the concept of comprehensiveness and, mainly, to develop the reflexive practice considering the complexity of the determinants that are part of the health-disease-care process.

\section{FINAL CONSIDERATIONS}

It can be assumed that once health professionals understand the concept of comprehensive care, this concept becomes an important instrument by breaking from an approach shaped by biological assumptions, and allowing the reconstruction of health practices based on the reception and expanded general practice with therapeutic projects constructed in an interdisciplinary way and integrated to the different levels of health care.

Considering the relevance of the nurse as a member of a multiprofessional team and the potential for this professional to act in a transformative perspective, highlighting the concept of comprehensive care is fundamental starting from the training of undergraduate students in the health area, so they have knowledge of the concept and are able to use it in the future - in teaching, research or extension projects. The training of critical professionals capable of acting in the strengthening of SUS in a committed manner ensures comprehensive health care and the transformation of the social and health reality of the population.

\section{REFERENCES}

1. Kalichman AO, Ayres JRCM. Comprehensiveness and healthcare technologies: a narrative on conceptual contributions to the construction of the comprehensiveness principle in the Brazilian Unified National Health System. Cad Saúde Pública [Internet]. 2016 [cited 2017 May 15];32(8):e00183415. Available from: http://www.scielo.br/pdf/csp/v32n8/1678-4464-csp-32-08-e00183415.pdf

2. Mattos RA. Os sentidos da integralidade: algumas reflexões acerca de valores que merecem ser defendidos. In: Pinheiro R, Mattos RA, (Orgs). Os sentidos da integralidade na atenção e no cuidado à Saúde. Rio de Janeiro: Uerj/IMS/Abrasco; 2006. p. 43-68.

3. Dyniewicz AM. Metodologia da pesquisa em saúde para iniciantes: sugestões e normas para trabalhos de conclusão de curso de graduação - TCCs e monografias de curso de especialização. São Caetano do Sul: Difusão; 2014.

4. Freire P. Pedagogia da autonomia: saberes necessários à prática educativa. São Paulo: Paz e Terra; 2011.

5. Breilh J. The social health determination as a tool of transformation towards a new public health (community health). Rev Fac Nac Salud Colectiva [Internet]. 2013 [cited 2018 Feb 22];31(Supl 1):S13-27. Available from: http://www.scielo.org.co/pdf/rfnsp/v31s1/v31s1a02.pdf

6. Barbosa Jr AJ, Perales PGPS, Vannuchi MTO, Martins EAP. The principle of integrality as guide to nurse formation. Espaç Saúde [Internet]. 2016 [cited 2017 Apr 12];17(1):101-6. Available from: http://espacoparasaude.fpp.edu.br/index.php/espacosaude/article/viewFile/373/13

7. Ayres JRCM. Care: work, interaction and knowing health practices. Rev Baiana Enferm [Internet]. 2017 [cited 2018 Feb 22];31(1):e21847. Available from: https://portalseer.ufba.br/index.php/enfermagem/article/viewFile/21847/14115

8. Colimoide FP, Meira MDD, Abdala GA, Oliveira SLSS. Integrality from the perspective of nurses in the Family Health Strategy. Rev Bioet [Internet]. 2017 [cited 2018 Jan 19];25(3):611-7. Available from: http://www.scielo.br/pdf/bioet/v25n3/en_1983-8042-bioet-25-03-0611.pdf

9. Lima MM, Reibnitz KS, Kloh D, Martini JG, Backes VMS. Indications of comprehensiveness in the pedagogical relationship: a design to be constructed in nursing education. Rev Esc Enferm USP [Internet]. 2017 [cited 2018 Feb 12];51:e03277. Available from: http://www.scielo.br/ pdf/reeusp/v51/en_0080-6234-reeusp-S1980-220X2016049003277.pdf

10. Souza EFD, Silva AG, Silva AILF. Active methodologies for graduation in nursing: focus on the health care of older adults. Rev Bras Enferm [Internet]. 2018 [cited 2018 Feb 12];71(suppl 2):920-4. Available from: http://www.scielo.br/pdf/reben/v71s2/0034-7167-reben-71-s2-0920.pdf 